\title{
The Concept of Calm Soul in The Qur'an
}

\author{
Marno $^{1}$, Marhamah ${ }^{2}$ \\ The Islamic University of Jakarta, Indonesia \\ The Islamic University of Jakarta, Indonesia
}

Email: habiebmarno11@gmail.com, Marhamahsyarif2@gmail.com

\begin{tabular}{ll}
\hline ARTICLE INFO & \multicolumn{1}{c}{ ABSTRACT } \\
\hline Date Received: 18 & This study aims to discover the influence of a calm soul to human life through \\
November 2020 & Allah's guidance and to take the lessons from Quranic verses about a calm \\
Revision Date : 16 & soul. The method of study is descriptive qualitative with the library research \\
december 2020 & (literature) which is compiled by the concept of Tafsir Maudhu'i. The results of \\
Date Received : 06 & this study show that muthmainnah verses more revealed after the prophet \\
January 2021 & migrated (hijrah). According to the word of muthmainnahin the Quran that \\
\hline Keywords: & related to the Nasr Hamid's idea in the pre-emigration phase, it is focused on \\
Calm; & the understanding or depiction of muthmainnah and its characteristics are that \\
Soul; & the quiet soul is the soul that returns to its blessed and blessed God, the soul \\
Muthmainnah; & that belongs to the servant of God and will enter heaven. Whereas the post- \\
Al-Qur'an & hijrah period, which contains in the muthmainnah word is more focused on the \\
& application of muthmainnah in dealing with various problems. \\
\hline
\end{tabular}

Coresponden Author:

Email: habiebmarno11@gmail.com Article with open access under license

\section{INTRODUCTION}

The Qur'an is a revelation revealed to the prophet Muhammad through the intervention of the Jibril for twenty-three years. The Quran is described by the Prophet as the "Divine Meal", a dish to help people understand and appreciate Islam and is a light for Muslims in dealing with various issues of life. values, norms, and actions that bring people to life and the hereafter. Allah SWT as the God of the universe has created man consisting of two elements namely material and immaterial (spirit, soul, and intellect). The fulfillment of both elements raises the inner conflict between good and evil, priority and humiliation, and obedience and disobedience to Allah.

The human soul has distinctive characteristics depending on the circumstances. The Qur'an mentions three characteristics of the soul namely; An-Nafs al-Ammarah bi as-su '(a soul that is constantly demanding to do evil), An-Nafs alLawwamah (a soul that is self-condemning), and An-Nafs al-Muthmainnah (a calm and peaceful soul). An-Nafs al muthmainnah is the noblest and highest soul compared to others because this soul is always in the truth without the slightest doubt. Itis illuminated by the light of the faith and is adorned with noble character and far from the ignoble matter.

Al-Qur'an explains that peace of soul is needed by humans, known as An-Nafs alMuttmainnah. Tranquility is a special trait that shows that people who can control the turmoil of their hearts and feelings and can control and drive it are also traits that indicate the harmony of the mental element and the compatibility between conflicting instincts, with their flexibility which is subject to the leadership of a healthy mind. Peace of mind is a mental condition of people who believe in Allah and adhere to the teachings of monotheism. Peace, peace, and peace are everyone's desires because all of them are a frame of happiness in life.

\section{Literature Study \\ The Definition of Soul}

In the language of "Soul (Nafs)" is defined as "something contained in a person" (Ma'luf, 2002: 39). As for the term according to sayyid Abu Hasan Ali bin Muhammad is "a jewel that is very gentle which brings strength to life, feelings, and activities desired, and he can also be equated as a judge of animal spirits, and he is a jewel for the body, then when he dies the light is cut off from the body and the heart clearly ". (Husen, 1987: 239).

In the Quran, the Souls (Nafs) are interpreted in several terms, including in the QS. As-Sham verses 7-8 are mentioned,"for the soul and its contents: the desire, the tendency and the habit" and the QS. Az-Zumar verse 42 is "Allah takes the soul (spirit) of man in his death".

According to Al-Farabi, the Soul (Nafs) is explained as "eternity as a whole (universal) and not eternal in the eternal form one by one among the souls of men". Meanwhile, according to Al-Kindi Soul (Nafs) is "a very subtle substance with noble character and its substance is part of the substance of Allah, even in it is the (soul) which is the light of His light"(Najar, 1998: 32-34).Al-Hakim At-Tirmidhi also defines the Soul (Nafs), which is "The soul is the earth of lust, inclined to lust after lust, and hope after doing hope"(Najar, 1998: 38-39).

The Definition of Muthmainnah 
According to JS Badudu and Sutan Mohammad Zen in the Indonesian General Dictionary, the word muthmainnah is interpreted as a form of calm, anxious opponents, restless and not shouting, no commotion, or riots or no conquest (Badudu, 1994: 1474).

In Lisan Al-Arab the word muthmainnahis derived from a tamanaor ta'mana word which has the added ziyadah form of hamzah to itma'anna which has the meaning of calming or quieting something. a place or space means being silent (Manzur, 1386: 204-205).

While according to the term, in Tafsir alMaraghi (Al-Maraghi, 1992: 260-261), muthmainnah is the peace of the soul after the shock. What it means is a resolution to what has been achieved after receiving a shake of coercion. FakhrurRazy, a well-known interpreter once told in the "Tafsir Kabir" that the human soul (heart) is one, but its attributes are numerous and varied. then it is callednafs al mutmainnah, a quiet and peaceful soul. If he is inclined to lust and anger he is called ammarah bi as sui , which is a heart full of evil (Al-Maraghi, 1992: 260-261).

Related to the discussion of the meaning of muthmainnah, as many people pair up the word nafs(read: nafs al-mutmainnah), calling it a study of psychology. There are three types of the psyche (an-lust) known in the Qur'an, first is an-nafsu alammarah. In the Qur'anhas written Inna annafsla'ammaratun bi assui (QS Yusuf (12): 53), Second is an-nafsu al lawwamah, In the Qur'an written "Walauqsimu bi an-nafs al -lawwamah" ( Surah al-Qiyamah (75): 2), and the third is an-nafsu al-muthmainnah. In the Qur'an it is written"Yaayyuha an-nafs al-mutmainnah, irji 'iilarabbikiradiyatanmardiyah" (QS al-Fajr (89): 27). In Tafsir al-Azhar, it is explained that what is called Nafs al Mutmainnah is a level of personality (soul) that has reached calmness.

Other definitions in Tafsir al-Azhar (Hamka, 1983: 153) include the soul that has been galvanized by experience and suffering. The soul that has gone through various winding roads so that no longer complains when climbing because behind the climb there must be a decrease. Also, the soul that is not happy jumped again when declining because it already knows behind the decline will be the climbing theme.

\section{The Definition of Nafs Al-Muthmainnah}

According to Ahmad Farid in his book Menyucikan Jiwa: Konsep Ulama Salaf describes that nafs al muthmainnah, always befriend with the angels. Through it, men seek guidance and encouragement in the truth of truth that adorns with the beauty of life. His presence can withstand every impulse of evil and to be able to reflect on all forms of evil and its consequences and sanctions, to avoid it. So, all human acts are purely for the sake of Allah, then it is a result of the nafs al mutmainnah.
Nafs al-mutmainnah along with the angels carry out the task of refreshing the human soul by monotheism, mercy, goodness, piety, tawakal, repentance, return to the path of Allah, not long in anticipation, preparing supplies to bring about death and life afterward. Meanwhile, the lust of the madman is based on the demonic command line he made his ally. He would always make empty promises, fill them with vanity, invite him to do evil, and decorate the crime as something interesting to him, through poisonous sweet words, controlling our brain as if we were to live forever. Ahmad Farid also describes two ways in evaluating the lust, they are:

1. One should stop thinking when he or she first plans to start a job. And do not rush to decide before the decision has no negative impact. Imam Hasan Basri said: "May Allah bless his servant who thinks for a moment when he does something, if it is for Allah, then he goes on and if it is beside him, he cancels it.

2. Evaluate yourself after doing charity, this can be done through three stages:

a. evaluates the lust for his obedience but he lacks the fulfillment of God's right to do so and in his execution does not work properly. The right of Allah in obedience is six things; sincerely doing, advising (expecting good) for Allah, following the teachings of the Messenger of Allah, manifesting the side of devotion in doing good, acknowledging Allah's gift of it and then acknowledging his inadequacy in doing so, thus man reckons himself from the criteria set by Him.

b. An introspection on every act that when left behind is more important than doing it.

c. Disguise yourself for an act that can (change) the law because it does. Regardless of whether he did it for Allah's sake and the life of the Hereafter, to be lucky, or to pursue the happiness of this mundane and temporal world, he regretted the future.

Meanwhile, Ibn Al-Jauzy in his book "Insult to the Lust" states to escape the trap (lust) of those who are embodied in it with a strong intention and determination to abandon the source of its cause. His method was to gradually, leave his monks, and he thought this required patience and struggle with the help of seven things:

1. Contemplate and think again that man was not created to be a slave to lust.

2. He should think of the consequences that lust will have.

3. Let the sensible person imagine that he has just fulfilled his lusts and has recalled the consequences of that action. Then he imagined again the danger that arises after only momentary pleasure. 
4. He should imagine if lust was done by people and then he thought of the results of lust in the mind if the disgrace befalls him.

5. He should rethink the pleasure he is pursuing, surely reason tells him that pleasure does not mean anything.

6. He should think about how he was overcome when he won and his humility when he lost. Indeed, no man can control his appetite unless he is strong in victory. And no one is coveted by their lust but will be despised and worthless.

7. It must mean the benefit of not following your desires. Among the benefits of restraining our passions are to gain the goodwill of the world, the safety of our soul and body, and the reward we have been promised in the hereafter.

Mutmainnah's soul has several forms of personality, namely; faith, confidence, sincerity, tawakal, repentance, taqarrub, patience, wisdom, piousness, calmness, and love for Allah and his messenger, fulfilling his commands and abstaining from his prohibition, courage, self-preservation, honesty, and compassion. Or in the hadith of the Prophet is simplified in the dimensions of faith, Islam, and mercy. These forms are motivated by positively theocentric beings surrounding mutmainnah's souls.

\section{METHOD}

This research was compiled using a qualitative descriptive method with the concept of the Tafsir Maudhui which is to gather all verses of the Qur'an that have the same goals and themes afterward arranged according to the chronology of the descent by paying attention to the causes of the descent. As for scientifically, this research is library research that is carried out using literature, both in the form of books, notes, and reports of research results from previous researchers aimed at collecting data and information. The data obtained with this library research can be used as a foundation and the main tool for conducting field research. This research is also said to be research that discusses secondary data.

\section{RESULT AND DISCUSSION \\ Muthmainnah's Versesin the Qur'an}

The discussion of Muthmainnah's verses in the Qur'an includes:

1. QS. Al-Baqoroh (2): 260

2. QS. Al-Imron (3): 126

3. QS. An-Nisa (4): 103

4. QS. Al-Maidah (5): 113

5. QS. Yunus (10):7

6. QS. Ar-Ra'd (13) : 28

7. QS. An-Nahl (16) : 106, 112

8. QS. Al-Isra (17) : 95

9. QS. Al-Hajj (22) : 11

10.QS. Al-Fajr (89) : 27

\section{Categorization of Makkiyahand Madaniyyaha} bout Muthmainnah's Versesin the Qur'an

The following is a table of categorization of Makkiyah and Madaniyyah verses of muthmainnnah:

1. Makkiyah category of muthmainnah's verses

\begin{tabular}{clcl}
\hline No & $\begin{array}{c}\text { Name of } \\
\text { Surah }\end{array}$ & Verse & Word Variation \\
\hline 1 & QS Al Fajr & 27 & mutmainnah \\
\hline 2 & QS An-Nahl & 106,112 & mutmainnun,Mutmainnah \\
\hline 3 & QS Yunus & 7 & itma'annu \\
\hline 4 & QS Ar-Ra'd & 28,2 & tatma'innu \\
\hline 5 & QS Al-Isra & 95 & mutmainin \\
\hline
\end{tabular}

\begin{tabular}{cccc} 
2. & \multicolumn{3}{c}{ Madaniyyah category of muthmainnah's verses } \\
\hline No & Name of Surah & Verse & \multicolumn{1}{c}{ Word Variations } \\
\hline 1 & QS Al-Imron & 10 & tatma'inna \\
\hline 2 & QS Al-Maidah & 113 & tatma'inna \\
\hline 3 & QS Al-Baqarah & 260 & iatma'inna \\
\hline 4 & QS Al-Hajj & 11 & itma'anna \\
\hline 5 & QS An -Nisa & 106 & itma'anna \\
\hline 6 & QS Al-Anfal & 10 & tatma'inna \\
\hline
\end{tabular}

Based on the table above it can be deduced that the verse of muthmainnah is more revealed after the Prophet's migration. Concerning the word muthmainnah associated with Nasr Hamid's thinking that in the pre-emigration period of the muthmainnah in the Quran the focus was on the understanding or depiction of muthmainnah and its characteristics that the quiet soul is the soul that returned to its blessed and blessed God, belong to the servant of God and will enter heaven. While in the post-migration period the discussion in the field of muthmainnah focused on the application of muthmainnahin dealing with various issues.

\section{Asbabun Nuzul of Muthmainnah's Versesin the Qur'an}

And some of the Qur'anic verses regarding the editorial of the muthmainnahitmainnu,yatmainnu , or tatmainnu which have the asbabunnuzulare;

1. QS. An-Nahl (16) : 106

Whoever disbelieves in Allah after his belief... except for one who is forced [to renounce his religion] while his heart is secure in faith. But those who [willingly] open their breasts to disbelief, upon them is wrath from Allah, and for them is a great punishment"

According to Ibn Abi Hatim's source from the Muahid, the asbab an-Nuzul of QS an-Nahl (16): 106 , is related to the existence of people of the Mecca who were sent by friends from Medina to emigrate. Then they left for Medina but could be followed by the Quraysh (disbelievers). Then the Quraysh infidels persecuted them and forced them to utter disbelief. The verse goes down about the event which confirms that those who are forced to utter the words of disbelief will be forgiven by Allah as long as they keep their faith (Dahlan, 2001: 315-316). 
In contrast to the history of Ibn Abi Hatim who came from Ibn Abbas, it is argued that the Ashbab an-Nuzul of the QS an -Nahl (16): 106 brought about a time when the Prophet was about to emigrate to Medina, the Muslims holding Bilal, Khabbab and 'Ammar Ibn Yasir. During his arrest, 'Ammar Ibn Yasir was able to escape by saying words that impressed them. Then this incident was reported to the prophet. Instead, the Prophet returned to 'Ammar Ibn Yasir "Is your heart empty when he says so" he answered "no" This verse QS an-Nahl (16): 106 is basically down concerning the fact that Allah will not be cursing the one who was forced to renounce but his heart still believing(Dahlan, 2001: 315-316).

2. QS. Al-Hajj (22) : 11

"And of the people is he who worships Allah on an edge. If he is touched by good, he is reassured by it; but if he is struck by trial, he turns on his face [to the other direction]. He has lost [this] world and the Hereafter. That is what is the manifest loss."

While asbab an-nuzul of the QS Al-Hajj (22): 11, according to al-Bukhari's account of Ibn Abbas, is when a man came to Medina and converted to Islam. He praises his religion when his wife gives birth to a boy and his horse breeds, but he insults his religion if his wife does not give birth to a baby boy and his horse does not breed. That is why the QS Al-Hajj (22): 11 is revealed(Dahlan, 2001: 356).

In the history of Ibn Marduwaih of Athiyyah which is derived from Ibn Mas'ud it is stated that the asbab an - nuzul of QS Al-Hajj (22): 11, is when a Jew converted to Islam, he became blind, his property was depleted, and his son died. Then he thought that it was Islam that made him unlucky. He said "I have never benefited from this religion. My eyes became blind, my property was destroyed, and my children died"(Dahlan, 2001: 356).

3. QS. Al-Fajr (89) : 27-29

"O reassured soul. Return to your Lord, well-pleased and pleasing [to Him].And enter among My [righteous] servants"

According to Ibn Abi Hatim, the origin of Buraidahis told that the asbab an nuzul of QS al-Fajr (89): $27-29$ is related to Hamzah who was martyred in the battlefield. However, in another story, Ibn Abi Hatim of Juwaibir, from adl-Dlahhak, quoted from Ibn Abbas that the Prophet (peace be upon him) said, "Who will buy the wells of Allah for forgiveness when Allah will forgive". The well was purchased by Uthman. The Prophet (saws) said: "Do you want the well to be a source of water for everyone? "Utsman said it. So Allah sent down QS Al-Fajr (89): 27 concerning Utsman.
Ibn Abbas interpreted muthmainnah with mushaddiqah, which is the justification of righteousness. When lust is in peace with the zikrullah, bow to Him, long for the encounter with Him - and be gentle when it is near, it is said, upon meeting his death, "O reassured soul. Return to your Lord, well-pleased and pleasing [to Him]" QS al-Fajr (89) 27-28.

However, the Qatadah says that the muthmainnah is a believer whose peace is in harmony with what Allah SWT has promised.Quietly enjoined on 'the knowledge of asma' and its nature-based on news from $\mathrm{Him}$ (the Qur'an) and His Messenger (as-Sunnah). Calm down by the news that comes after death, the barbarian nature, and the events of the Day of Judgment, they seem to see it with bare eyes. Relying on God's destiny, accepting and pleading with him, not hating, and groaning, nor shaking his faith, never despairing of something that is gone from him, not proud of what he has. With this intention, all misfortunes were predestined by Him long before they came to him, even before he was created. Allah SWT says "No misfortune comes except by Allah's permission. And whoever believes in Allah, $\mathrm{He}$ will guide his heart" (QS.at-Taghabun (64): 11). Not a few salaf who interpret it as someone who is afflicted by disaster, he understands that the disaster came from Allah so he was pleased and resigned. If a soul is calm, then the soul has moved from doubt to belief, from ignorance to knowledge, from vanity to remembrance, from treachery to repentance, from riya to sincerity, from falsehood to honesty, from weakness to redeeming spirit, from the nature of temptation to submission, and from error. to the forefront, that is when lust is at peace.

\section{DISCUSSION}

The Concept of Muthmainnahin the Qur'an

The Qur'an is a scripture that gives direction to the straight path, giving glad tidings to believers doing good deeds. Manna 'al-Qaththan says "The Quran is the eternal miracle of Islam whereas science progresses, the more valid the miracle becomes" (Al-Qathan, 2007: 3). Al-Qur'an which calls itself as a guide for humans (hudan li an-nas) becomes blurred along with human arrogance. One of the demands of the Qur'an is to form a complete human being with a pious personality called annafsu al-mutmainnah. Here are some Analyzes of muthmainnah verses in the Qur'an:

1. QS. Al-Baqoroh (2): 260

This verse talks about how Ibrahim sought to strengthen his faith or belief by asking Allah the question of how to raise the dead. By the time Ibrahim sent his request, he had not yet reached a level of convincing faith so there were still questions that popped into his mind. 
According to the author, liyatmainnaqalbimeans the power of faith and greatness of Allah.

2. QS. Ar-Ra'd (13) : 28

This verse talks about peace caused by dzikrullah. Dzikirwill bring peace to the soul when it is intended to push the heart towards the awareness and power of Allah Almighty rather than by speaking with the tongue. According to Thabathaba'l, the word tatmainna (being peaceful) is an explanation of the earlier word which is faith. Furthermore, based on Quraish Shihab the word tatmainnauses the present form of verbs which is not to describe the occurrence of peace at a certain time but to mean continuity and stability.

3. QS. Al-Imron (3) : 126 and QS. Al-Anfal (8) : 10

These two verses speak of the good news of Allah's help to be given to Muslims. From the two verses above the word litatmainnaqulubaqum according to the author is a peace that arises because of the belief in Allah's help to face all problems but must meet the conditions of patience and devotion that Allah has determined.

After analyzing some of the muthmainnah verses, the author can map the concept of muthmainnah in the Qur'an into three parts: first, muthmainnah or peace that arises because of the stability of faith one has with the recognition of Allah's power and greatness. Second, muthmainnah or peace that arises because of the remembrance of Allah's mercy and compassion and has knowledge based on awareness of the greatness of Allah. Third, muthmainnah or peace that arises because of the belief in Allah's help in dealing with everything by being able to carry out the conditions of patience and devotion that Allah has set.

When referring to the verses that explain the nafs al-mutmainnah, the existence of the muthmainnah personality is driven by two factors:

1. Internal Factor, in the form of human heart which has divine nature. If the heart is fully convinced of the greatness of Allah, then it can assure peace and faith, as stated in the letter of alBaqarah (2): 260.

2. External Factor, in the form of care and guidance from Allah swt. Hidayah (guidance) from Allah is extremely helpful for humans in finding their identity. Humans with their abilities without guidance will be difficult to find their identity.

\section{Contextualization of Muthmainnah in the Reality} of Life

In Islam, humans are the central target of their teachings, both the relationship between humans and their God, the relationship between human beings and nature. The most complex is the number two relationship, which is the relationship between humans. For this reason, Islam teaches concepts about human status, rights, and obligations and responsibilities. What is done by humans not only have value and consequences in the world, but also the hereafter (Azizy, 2004: 160). With attention to the integration of knowledge insight, in this level, there is a symbolic relationship between belief and worship with science.Belief and worship must be supported by knowledge, while useful knowledge must have implications for increasing faith and worship. Muthmainnah's personality requires its owner to always be in harmony with his life journey between worldly and ukhrowi during this rapid development, which often leads people towards materialistic life. With muthmainnah personality, a person is expected to experience peace and tranquility to eliminate or at least reduce the various feelings of anxiety, complaints, and psychological consequences that are experienced by many modern humans.

Muthmainnah in the form of tuma'ninah does not mean silent, static, and stop because in tuma'ninah there are activities that are accompanied by feelings of calm. This can be seen that the dynamics of tuma'ninah in prayer have a harmonious rhythm. Sometimes human raises his hands, stands up, bows down, returns to his feet, kneels, and sits down. Such dynamics describe all human behavior in navigating life. The calmness felt by individuals is caused by the creativity that is carried out still in the correct procedure, does not violate the rules, and is not showed at all to commit treason.

Muthmainnah is a positive force that shapes a person's personality with the perfect balance between worldly and ukhrawi values. It means that transforming and actualizing values in worship demands ritual rites and practices them in the actual form of piety, which is a formto cultivates faith and piety, and also as the seed that will build the generositywith wahdah al-aqidah as the main mission. Together with wahdah al-aqidah, the social system approach is used to construct wahdah algayah (similarity of goal) which will build wahdah alsy'ur (similarity of sense). The individuals in this social community will be more beneficial than demanding and blaspheming, more sacrificing than receiving the help of others, more spreading virtue than spreading slander and hostility.

The reality that occurs in our lives shows many Muslims are trapped by vertical physical worship without meaning. They assume that piety is only obtained by serving Allah Almighty through formal worship (mahdah) which solely persuades Allah so that his request is granted. Meanwhile, social piety in developing humanism and solidarity among people has not received the proper part. Until now, it seems that many people are religious but cannot explain their religious teachings when faced with complex humanitarian issues. With muthmainnah personalities, Muslims are required to be human beings who are divine without ignoring worldly piety. The uniqueness of the concept of 
Islamic personality lies in muthmainnah personality. This personality is theocentric which is controlled by the structure of the heart. Based on these personality criteria, the concept of Islamic personality is that the center of human personality is the heart because the heart is the highest structure in the Islamic personality. Al-Ghazali states that "the heart is a virtuous structure to know all that is (the essence)" (Dunya: 143).With the heart, the human personality is not merely embodying the personality of an insaniyyah but also required to achieve a divine personality. Human personality is expressed as a conscious personality, while the divine personality is expressed as a superconscious personality. From this criterion, actualization, selfrealization, and its development do not merely end at the stage of consciousness but are sought at the supra-awareness stage which can be created in the form of obedience and to the Creator (Allah).

\section{CONCLUSION}

Muthmainnah is the tranquility of the soul that is inclined to Allah's values and Allah's instructions.Muthmainnah is a believing soul and is not tickled by fear and heartache. Muthmainnah can be interpreted as a sincere soul, who is sure, who has faith and is also a happy soul with the provisions of Allah who knows if something destined to be his part will surely come to him. The calm soul grows because of the ability to place things in their proper place, and always places them based on faith. With this faith, man will accept everything he faces, both happy and difficult, both winning and losing and others with pleasure.

In other condition, those who have muthmainnah personality, can control their self under any circumstances, think rationally, able to create balance in their self, and their hearts remain calm and peace. Those calm souls always feel happy to face whatever the circumstances, also gain Allah's ridha. In the Qur'an, the nafs almutmainnah is driven by two factors: first, Internal Factor, in the form of human heart which has divine nature, if the heart is fully convinced of the greatness of Allah, then it can assure peace and faith. Second, External Factor, in the form of care and guidance from Allah SWT. Hidayah (guidance) from Allah is extremely helpful for humans in finding their identity.

\section{REFERENCES}

Abduh, M., Ridho, R. 1997. Tafsir al-Manar. Beirut: Dar al Fikr.

Al Suyuti, J. 2006. Samudra Ulumul Quran. Surabaya : PT Bina Ilmu. Al-Farmawi, A.H. 1977. Al-Bidayah Fi At-Tafsir Al-Maudhu'l. Kairo :MaktabahJumhuriyah.
Al-Ghazali, A.H. 1997. Al -Munqizmin al-Dalal. Beirut : Dar al Fikr.

Al-Maraghi, A.M. 1992. Tafsir Al-Maraghi. Semarang :KaryaTohaPutra.

Al-Qaththan, M. 2007. PengantarStudillmu AlQur'an. Jakarta : Pustaka Al-Kautsar.

Anwar, R. 2005. IlmuTafsir. Bandung : Pustaka Setia.

Azizy, A.Q. 2004. MelawanGlobalisasi. Yogyakarta : Pustaka Pelajar.

Badudu, J.S., Zein, M.S. 1994. KamusUmum Bahasa Indonesia. Jakarta : Pustaka Sinar Harapan.

Baidan, N. 2000. MetodologiPenafsiran al-Quran. Yogyakarta: Pustaka Pelajar.

Burckhardt, T. 1984. MengenalAjaranKaum Sufi. Jakarta : Pustaka Jaya.

Dahlan, H.A.A., Al Farisi, M.Z. 2001. Asbab an Nuzul. Bandung : CV Diponogoro.

Farid, A. 2004. Tazkiyah An-Nafs, KonsepPenyucian Jiwa Menurut Para Salaf. Solo : Pustaka Arafah.

Hamka. 1983. Tafsir Al-Azhar. Jakarta : Pustaka Panjimas.

Hasan, I. 2001. Sejarah dan Kebudayaan Islam. Jakarta : Kalam Mulia.

Majid, N. 1994. KontekstualisasiDoktrindalam Sejarah. Jakarta: Paramadina.

Manzur, I. 1386. Lisan Al-'Arab. Beirut :DarulFikri.

Marzuki, K. 1994. ‘Ulum Al-Qur’an. Bandung : PT RemajaRosdaKarya.

Mubarok, A. 2000. Jiwa dalam al-Qur'an. Jakrta :Paramadina

Mujib, A. 2006. KepribadianDalamPsikologi Islam. Jakarta : PT Raja Grafindo.

Najati, M.U. 1985. Al-Quran wa 'Ilmu al-Nafs. Bandung : Pustaka Setia.

Najati, U. 1997. Al-Qur'an dan Ilmu Jiwa. Bandung : Pustaka. 
Nashir, H. 1997. Agama dan KrisisKemanusiaan Modern. Yogjakarta : Pustaka Pelajar.

Noer, J. 2006. PembinaanSumberDayaManusiaBerkualitas dan BermoralMelaluiShalat yang Benar. Jakarta :Kencana.

Rais, M.A. 1998. Tauhid Sosial : Formula MenggempurKesenjangan. Bandung :Mizan.

Razzaq, A. 1984. Al-Kalasyani :Mu'jamal-Istilahat as Suffiyyah. Kairo: Dar al-Ma'arif.

Saefudin, D. 2012. MetodologiStudi Islam. Tanggerang :SeratAlam Media.

Sarwono, S.W. 1999. PsikologiSosial. Jakarta :Balai Pustaka.

Shihab, M.Q. 1996. Wawasan Al - Qur'an. Bandung: Mizan.

Shihab, M.Q. 1999. Mukjizat Al-Quran ditinjaudariAspekKebahasaan. Bandung :Mizan.

Shihab, M.Q. 2000. Tafsir al-Mishbah: Pesan, Kesan dan Keserasian Al-Qur'an. Jakarta :Lenterahati.
Shihab, M.Q. 2006. MenaburPesanllahi. Jakarta :LenteraHati.

Siraj, S.A. 2006. TasawufsebagaiKritikSosial. Bandung :Mizan.

Sugiyono. 2009. Metodepenelitiankualitatif dan kuantitatif. Bandung, Alfa Beta.

Syafe'i, R. 2006. PengantarllmuTafsir. Bandung : Pustaka Setia.

Syauqi, A. 2012. Misteripotensigaibmanusia. Jakarta :Qisthi press.

Taimiyah, I. 1977. Muqaddimah fi Usul-Tafsir. Beirut: Dar IbnuHazm.

Zaid, N.H.A. 2005. Tektualitas al-Qur'an kritikterhadapUlum al-Qur'an. Yogyakarta : PT Pelangi Aksara.

Zarqani, M.A.A. 2002. Manahil al-irfan fi ulumul Qur'an. Jakarta : Gaya Media Pratama. 